\title{
Evaluation of the Ecotoxicological State of Selected Soils from Urban Environments of Russian Arctic with the Aim to Substantiate Reclamation and Restoration Strategies
}

\author{
Ivan Alekseev ${ }^{1}$, Evgeny Abakumov ${ }^{1}$, Alina Petrova ${ }^{1,}{ }^{,}$, and Lubov Vorona-Slivinskaya ${ }^{2}$ \\ ${ }^{1}$ St.Petersburg State University, Universitetskaya naberezhnaya, 7/9, St. Petersburg, 199034, Russia \\ ${ }^{2}$ Saint Petersburg State University of Architecture and Civil Engineering, Vtoraya Krasnoarmeiskaya \\ str. 4. St. Petersburg, 190005, Russia
}

\begin{abstract}
In recent decades rates of anthropogenic forcing on natural and urban ecosystems in the Arctic are increasingly growing. This tendency requires the development of more detailed environmental monitoring methods. In this context, study of background trace elements contents should be an urgent task. The purpose of authors study was an assessment of trace elements content in soils of urban environments in Yamal region and Murmansk. Twelve sites in Yamal region and four sites in Murmansk in different functional zones were studied during the investigation. Samples were taken from a depth of $0-5 \mathrm{~cm}$ and $5-20 \mathrm{~cm}$. The highest contents for $\mathrm{Cu}, \mathrm{Zn}, \mathrm{Ni}$ were found in soil samples from Kharp, which was caused by existing chrome-processing factory. Soil samples from Aksarka and Labytnangi were characterized by the highest median values for $\mathrm{Pb}$. Soil samples from Kharsaim and Kharp key plots were characterized by the highest median values for $\mathrm{Zn}$. This could be explained by geological origin and high regional background concentration element for this trace element. Soil samples collected in Murmansk were characterized by highest medians in $\mathrm{Pb}, \mathrm{Ni}$ and $\mathrm{Mn}$ in topsoil horizons, $\mathrm{Mn}$ and $\mathrm{Zn}$ in lower horizons. Evaluation of Saet's index showed the predominance of nonhazardous $\mathrm{Zc}$ in most of the soil samples. Predicted climate change and consequent degradation of permafrost in soils could have the behavior of trace elements. Rates of accumulation, transformation, translocation, leaching and transportation of trace elements and other pollutants within the permafrost-affected landscapes could be affected and changed significantly.
\end{abstract}

\section{Introduction}

Soils and soil cover play a critical role in Arctic polar ecosystems determining their geochemical regime and stability to external effect directly through accumulation, migration and transformation of energy and matter and indirectly via transformation of

\footnotetext{
* Corresponding author: petrova.1992@mail.ru
} 
flows and processes. Increasing rates of anthropogenic effects on natural and urban ecosystems in the Arctic requires development of more detailed environmental monitoring system and applied tools. In this context, study of background trace elements concentrations should be an urgent task. At the same time heavy metals are naturally the part of parent materials and soils appearing in the form of sulfides, oxides, silicates, and carbonates [1]. Heavy metals are considered as the major group of anthropogenic pollutants in soils. Previously conducted studies showed that trace metals could reach the Arctic by different paths both anthropogenic and natural [1-6]. Permafrost-affected soils are also the great storage of carbon and accumulate a great amount of organic matter [8]. Organic matter is capable of forming organo-minerals associations [9]. Therefore, soil organic matter hence could retain various trace elements by different mechanisms: the ionexchange, proton displacement, and inner or outer-sphere complex formation [10]. West Siberian Arctic environments are being developed intensively due to the exploration of oil and gas. The problem of environmental restoration and environmental management is an urgent objective in Yamal, Taz and southeast Gydan Peninsula [11, 12]. Yamal region is actively developing in recent decades. It is one of the richest region in context of oil and gas deposits. Rise of urban area leads to enhancing of pollution risks by sources connected to the settlements $[13,14]$.

Moreover, urban areas could be considered as areas with increased risk in context of trace elements and will continue to be so for a long time, according to predictions [7].

Research of pollutant behavior in both urban and natural soils seems to be one of the most important issues for investigations in further decades. Such investigations could be used for making accurate risk assessments concerning such aspects as human health and long-term ecological effects. Approaches for establishment of the limit values and identification priorities concerning the remediation of contaminated sites could also be developed [7]. Data about the trace elements content in soil of the Arctic is limited and should be stated as insufficient. Evaluation of anthropogenic impacts on Arctic ecosystems requires not only background levels of trace metals, but also landscape distribution of elements in permafrost-affected soils in relation to soil properties [1, 15-18]. This study was aimed at evaluation of trace elements content of urban soils in Yamal region and Murmansk.

\section{Materials and methods}

The investigation was conducted on the territory of Yamal autonomous region within the settlements (Aksarka, Kharsaim, Kharp, Labytnangi, Salekhard) and Murmansk. Both regions are referred to the zone of discontinuous permafrost.

Soil classification was conducted according to "Classification and diagnostics of Russian soils» and World Reference Base for Soil resources. Detailed description of studied key plots is given in Table 1 .

Table 1. General information on studied key plots.

\begin{tabular}{|c|l|l|c|}
\hline Key plot & $\begin{array}{l}\text { Geographical } \\
\text { coordinates }\end{array}$ & $\begin{array}{l}\text { Functional } \\
\text { zone/Landscape } \\
\text { description }\end{array}$ & $\begin{array}{l}\text { Name of the soils in WRB (2014); } \\
\text { Russian soil classification system (2008) }\end{array}$ \\
\hline Aksarka & $\begin{array}{l}\text { N66 } 33^{\prime} 54,3^{\prime \prime} \\
\text { E } 67^{\circ} 48^{\prime} 04,8^{\prime \prime}\end{array}$ & $\begin{array}{c}\text { Recreational } \\
\text { functional zone }\end{array}$ & Urbic Technosol; Urbanozem \\
\hline Kharsaim & $\begin{array}{l}\text { N66 } 65^{\circ} 54,7^{\prime \prime} \\
\text { E } 67^{\circ} 18^{\prime} 34,2^{\prime \prime}\end{array}$ & $\begin{array}{c}\text { Recreational } \\
\text { functional zone }\end{array}$ & Urbic Technosol; Urbanozem \\
\hline Salekhard & $\begin{array}{l}\text { N66 } 63^{\circ} 31,9^{\prime \prime} \\
\text { E } 66^{\circ} 34^{\prime} 07,2^{\prime \prime}\end{array}$ & $\begin{array}{c}\text { Residential functional } \\
\text { zone }\end{array}$ & Urbic Technosol; Urbanozem \\
\hline
\end{tabular}




\begin{tabular}{|c|c|c|c|} 
Labytnangi & $\begin{array}{c}\text { N66 } 40^{\prime} 01,1^{\prime \prime} \\
\mathrm{E} 66^{\circ} 20^{\prime} 59,6^{\prime \prime}\end{array}$ & $\begin{array}{c}\text { Industrial functional } \\
\text { zone }\end{array}$ & Urbic Technosol; Technozem \\
\hline Kharp & $\begin{array}{c}\text { N66 } 68^{\prime} 34,0^{\prime \prime} \\
\mathrm{E} 65^{\circ} 47^{\prime} 08,0^{\prime \prime}\end{array}$ & $\begin{array}{c}\text { Industrial functional } \\
\text { zone }\end{array}$ & Urbic Technosol; Technozem \\
\hline Murmansk & $\begin{array}{c}\text { N } 68^{\circ} 58^{\prime} 45^{\prime \prime} \\
\text { E } 33^{\circ} 05^{\prime} 33^{\prime \prime}\end{array}$ & $\begin{array}{c}\text { Recreational } \\
\text { (x2)/Industrial/Reside } \\
\text { ntial functional zone }\end{array}$ & $\begin{array}{c}\text { Podsol/Urbic Technosol/Entic Podzol; } \\
\text { Torfyano-stratozem/Torfyano-Podzol } \\
\text { gleeviy/Urbo-stratozem/Torfyano- } \\
\text { Podbur gleeviy }\end{array}$ \\
\hline
\end{tabular}

Ecotoxicological state of Russian Arctic cities is underestimated. Therefore this research was aimed at investigation of trace metals content in soils of both Yamal and Murmansk urban environments, and estimation of the profile trends of trace metals distribution in permafrost-affected soils of studied urban areas. During the investigation twelve sites in Yamal region and four sites in Murmansk were studied. Samples were taken from a depth of $0-5 \mathrm{~cm}$ and $5-20 \mathrm{~cm}$. Soil samples have been collected in industrial (Labytnangi, Kharp, Murmank), residential (Salekhard), recreational functional zones (Aksarka, Kharsaim, Murmansk). Laboratory analysis was conducted in the Komi Scientific Centre Laboratory of the Russian Academy of Sciences. Trace elements contents $(\mathrm{Pb}, \mathrm{Cu}, \mathrm{Ni}, \mathrm{Zn}, \mathrm{Mn})$ were determined with an X-ray fluorescent analyzer «SpectroscanMAX». The obtained values were compared with the permissible concentrations and maximum allowable concentrations adopted in Russia, which are contained in special normative documents.

Background concentrations of heavy metals were taken from the obtained data for natural soils of Beliy Island $[6,19]$. The Clarke concentration in Earth's crust was taken as a background concentration of lead.

\section{Results and discussions}

Data about soil chemical properties was determined for fine earth (Table 2). Obtained data indicated that soils are characterized by following features. Soils were characterized principally by strongly acidic $(\mathrm{pH} 5.1-5.5)$ conditions in Kharsaim, slightly acidic and almost neutral (pH 6.1-6.9) conditions in Aksarka, Labytnangi and Murmansk (Table 2). The $\mathrm{pH}$ values were characterized mostly as strongly acidic ( $\mathrm{pH}$ 4.7-5.1) for Salekhard and Kharp key plots. Particle size distribution analysis showed predominance of silt fraction in soils of key plots located on the river terraces of $\mathrm{Ob}^{\prime}$ River (Aksarka, Kharsaim) and predominance of sand fraction in soils of the other key plots (Salekhard, Labytnangi, Kharp, Murmansk) (Table 2). The total organic carbon content in studied soil samples showed relatively high variability (values ranged between $0.19 \%$ and $14.58 \%$ ). It might be caused by high heterogeneity of soil material in studied technosoils due to the mixing caused by human activity.

Results about the trace elements content for investigated key plots in urban environments of Yamal region and Murmansk are summarized in Figure 2. The highest concentrations for $\mathrm{Cu}, \mathrm{Zn}$, Ni were found in the Kharp key plot which was probably caused by existing chrome-processing factory. The highest median values for $\mathrm{Pb}$ were found in soil samples from Aksarka and Labytnangi key plots. Soil samples from Kharsaim and Kharp key plots were characterized by the highest median values for $\mathrm{Zn}$. This could be explained by geological origin and high regional background concentration element for this trace element [19]. 
Table 2. Standard soil characteristics of studied key plots.

\begin{tabular}{|c|c|c|c|c|c|c|}
\hline \multirow[b]{2}{*}{ Soil ID } & \multirow[b]{2}{*}{ Depth, cm } & \multirow[b]{2}{*}{ TOC, $\%$} & \multirow{2}{*}{$\begin{array}{l}\mathrm{pH} \text { in } \\
\text { water }\end{array}$} & \multicolumn{3}{|c|}{ Particle size distribution, $\%$} \\
\hline & & & & Clay & Silt & Sand \\
\hline \multicolumn{7}{|c|}{ Kharsaim } \\
\hline $\mathrm{Km} 1$ & $0-5$ & 9,47 & 5,7 & 20 & 65 & 15 \\
\hline $\mathrm{Km} 1$ & $5-20$ & 2,13 & 5,2 & 17 & 70 & 13 \\
\hline $\mathrm{Km} 2$ & $0-5$ & 0,41 & 5,2 & 31 & 53 & 16 \\
\hline $\mathrm{Km} 2$ & $5-20$ & 0,19 & 5,25 & 25 & 62 & 13 \\
\hline \multicolumn{7}{|c|}{ Aksarka } \\
\hline Aks1 & $0-5$ & 0,23 & 5,87 & 20 & 73 & 7 \\
\hline Aks1 & $5-20$ & 3,23 & 6,93 & 17 & 61 & 12 \\
\hline Aks2 & $0-5$ & 3,49 & 6,42 & 25 & 63 & 12 \\
\hline Aks2 & $5-20$ & 5,69 & 6,33 & 35 & 48 & 17 \\
\hline \multicolumn{7}{|c|}{ Salekhard } \\
\hline Sal1 & $0-5$ & 3,24 & 4,92 & 23 & 30 & 47 \\
\hline Sal1 & $5-20$ & 0,93 & 4,78 & 12 & 25 & 63 \\
\hline $\mathrm{Sal} 2$ & $0-5$ & 1,56 & 5,67 & 17 & 31 & 52 \\
\hline $\mathrm{Sal2}$ & $5-20$ & 3,26 & 6,39 & 6 & 19 & 75 \\
\hline Kh1 & $0-5$ & 0,84 & 4,71 & 16 & 20 & 64 \\
\hline Kh1 & $5-20$ & 14,58 & 5,43 & 14 & 34 & 52 \\
\hline $\mathrm{Kh} 2$ & $0-5$ & 6,34 & 5,06 & 15 & 29 & 56 \\
\hline Kh2 & $5-20$ & 3,75 & 6,09 & 14 & 25 & 61 \\
\hline \multicolumn{7}{|c|}{ Labytnangi } \\
\hline Lab1 & $0-5$ & 3,89 & 6,39 & 17 & 28 & 65 \\
\hline Lab1 & $5-20$ & 4,38 & 6,32 & 12 & 18 & 70 \\
\hline Lab2 & $0-5$ & 4,54 & 6,42 & 9 & 19 & 72 \\
\hline Lab2 & $5-20$ & 5,23 & 4,9 & 9 & 27 & 64 \\
\hline Lab3 & $0-5$ & 5,23 & 6,42 & 11 & 35 & 54 \\
\hline Lab3 & $5-20$ & 4,53 & 6,32 & 12 & 17 & 71 \\
\hline \multicolumn{7}{|c|}{ Murmansk } \\
\hline Mur1 & $0-5$ & 3,99 & 6,43 & 19 & 23 & 68 \\
\hline Mur1 & $5-20$ & 4,70 & 6,1 & 15 & 21 & 64 \\
\hline Mur2 & $0-5$ & 4,60 & 6,25 & 14 & 24 & 62 \\
\hline Mur2 & $5-20$ & 5,50 & 5,12 & 8 & 31 & 61 \\
\hline
\end{tabular}

Soil samples collected in Murmansk were characterized by highest medians in $\mathrm{Pb}, \mathrm{Ni}$ and $\mathrm{Mn}$ in topsoil horizons, and $\mathrm{Mn}$ in lower horizons (Mur1 and Mur3 - recreational functional zone); $\mathrm{Mn}$ and $\mathrm{Zn}$ (Mur2 - industrial functional zone); $\mathrm{Mn}$ and $\mathrm{Ni}$ in topsoil horizon, $\mathrm{Mn}$ and $\mathrm{Zn}$ in lower horizon (Mur4-residential industrial zone). Since soil samples in Murmansk were collected from less-disturbed soils (compared to highly human-mixed soil material in settlements of Yamal autonomous region) profile distribution of trace elements seems to be similar to analogical in natural soils of the Arctic region reported in 
previous works $[6,19,20]$. It means that the highest contents of trace elements occurred in histic topsoil horizons or on the biogeochemical barriers (which could be developed on the active layer-permafrost border or in redoximorphic conditions).

\section{Kharsaim}
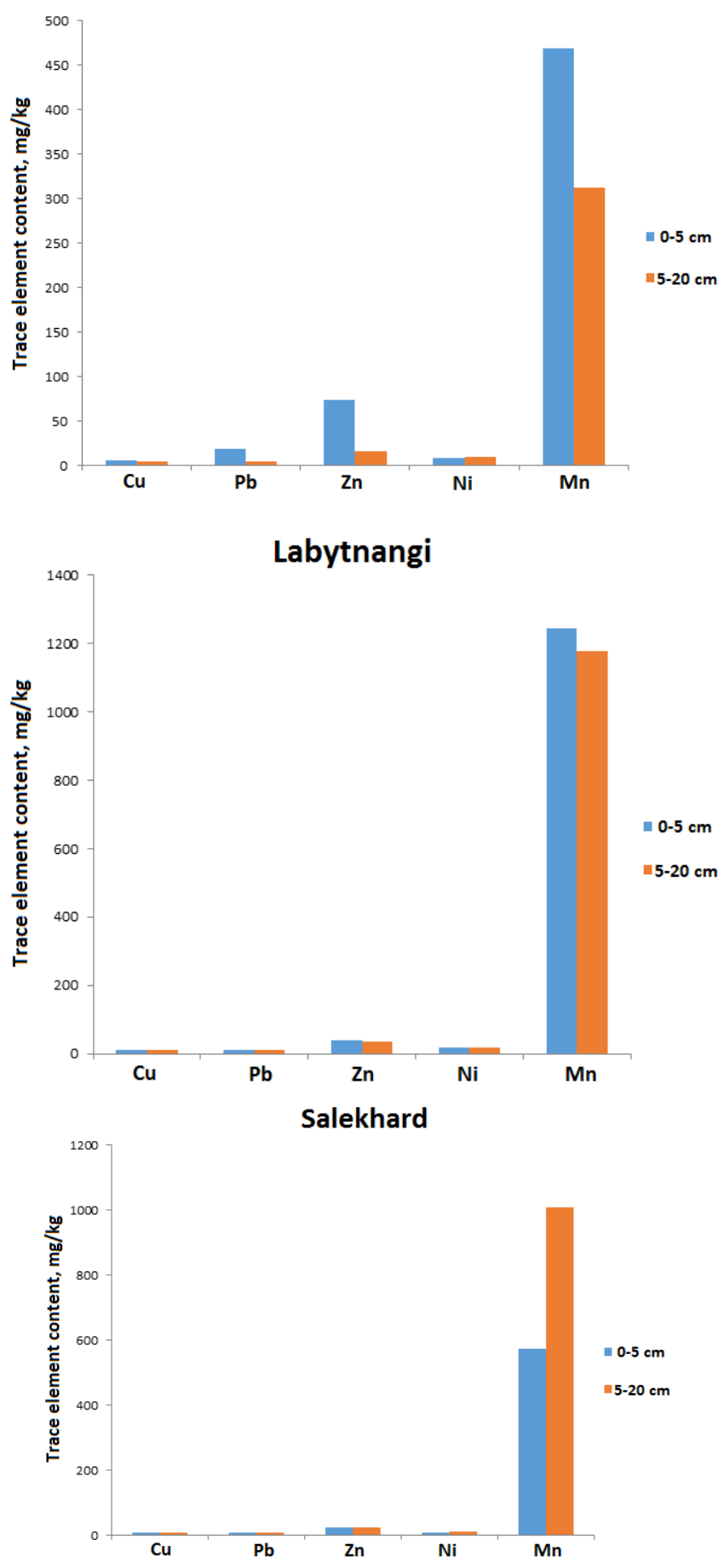


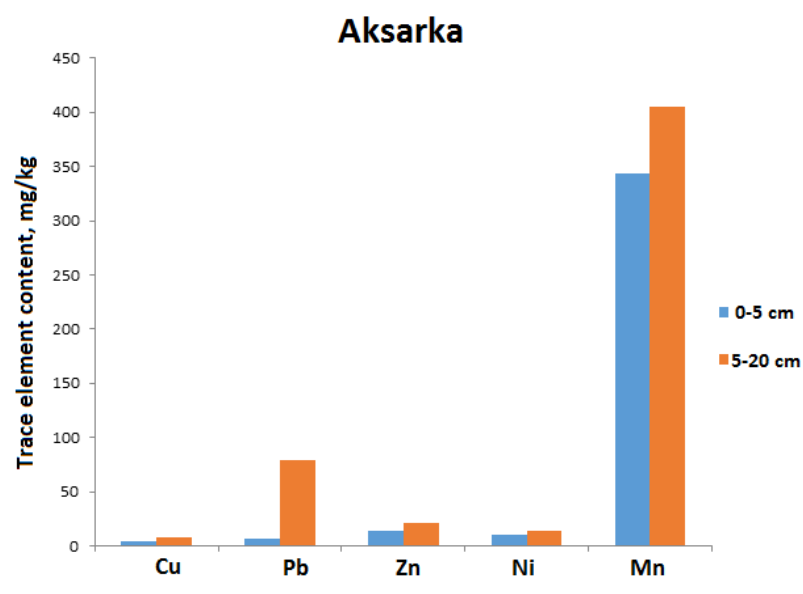

Murmansk

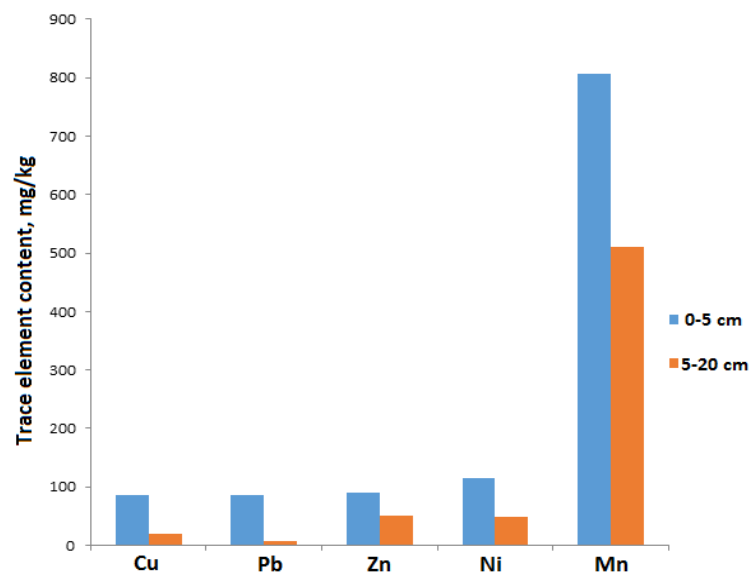

Fig. 1. Trace elements content in urban soils of Yamal region and Murmansk.

The calculation of Saet's index (Zc) was also performed. Not only average arithmetic values of coefficient of concentration (Kk) were used, but also its average geometric values. Most of the soil samples were characterized by non-hazardous $(\mathrm{Zc}<16)$ levels of total soil contamination. This fact characterized soils as unpolluted. Saet's index was determined at levels of $(16<\mathrm{Zc}<32$, moderately dangerous level) just in few soil samples from Aksarka and Kharp. The rest soil samples were characterized by $\mathrm{Zc}<16$ (non-dangerous level of contamination).

Degradation of permafrost could alter the behavior of trace elements in soils. It could affect the rates of accumulation, transformation, translocation, leaching and transportation of trace elements and other pollutants within the permafrost-affected landscapes. Consequently, ecosystem services provided by urban soils should be investigated in context of predicted climate change [21-23]. All the hydraulic works [24], hydropower plants exploitation [15-24] should be done according with the soil pollution protection measures, so as with the application of different soil hydrophysical properties investigation [25-26].

\section{Summary}

Analysis of obtained data showed the highest concentrations for $\mathrm{Cu}, \mathrm{Zn}$, $\mathrm{Ni}$ in soil samples from Kharp. It could be probably caused by existing chrome-processing factory. The 
highest median values for $\mathrm{Pb}$ were found in soil samples from Aksarka and Labytnangi. Soil samples from Kharsaim and Kharp key plots were characterized by the highest median values for $\mathrm{Zn}$. This could be explained by geological origin and high regional background concentration element for this trace element. Soil samples collected in Murmansk were characterized by highest medians in $\mathrm{Pb}, \mathrm{Ni}$ and $\mathrm{Mn}$ in topsoil horizons, and $\mathrm{Mn}$ in lower horizons (Mur1 and Mur3 - recreational functional zone); Mn and Zn (Mur2 - industrial functional zone); $\mathrm{Mn}$ and $\mathrm{Ni}$ in topsoil horizon, $\mathrm{Mn}$ and $\mathrm{Zn}$ in lower horizon (Mur4residential industrial zone).

Evaluation of Saet's index revealed that most of the soil samples were characterized by non-hazardous $(\mathrm{Zc}<16)$ levels of total soil contamination. It characterized soils as unpolluted. Saet's index was determined at levels of $(16<\mathrm{Zc}<32$, moderately dangerous level) just in few soil samples from Aksarka and Kharp. The rest soil samples were characterized by $\mathrm{Zc}<16$ (non-dangerous level of contamination).

\section{Acknowledgments}

This study was supported by Russian Foundation for basic research, grant 1634-60010, Russian presidents' grant for Young Doctors of Science № MD-3615.2015.4, the Government of the Yamal autonomous region and Grant of Saint-Petersburg State University "Urbanized ecosystems of the Russian Arctic: dynamics, state and sustainable development".

\section{References}

1. I. Antcibor, A. Eschenbach, S. Zubrzycki, L. Kutzbach, D. Bolshiyanov, E.-M. Pfeiffer, Russia. Biogeosciences, 11, 1-15 (2014).

2. L.A. Barrie, D. Gregor, B. Hargrave, R. Lake, D. Muir, R. Shearer, B. Tracey, and T. Bildeman, Sci. Total Environ., 122, 1-74 (1992).

3. K.A. Rahn, U. Tomza, and T.V. Khodzher, J. Aerosol Sci., Elsevier Science, 28(1), 465-466 (1997).

4. F. Rovinsky, B. Pastuchov, Y. Bouyvolov, and L. Burtseva, Sci. Total Environ., 160/161, 193-199 (1995).

5. D.J. Thomas, B. Tracey, H. Marshall, and R.J. Norstrom, Sci. Total Environ., Elsevier Science Publishers, 122, 135-164 (1992).

6. N. Arefiev, V. Garmanov, V. Bogdanov, Yu. Ryabov, V. Terleev, V. Badenko, Procedia Engineering, 117, 26-31 (2015).

7. M. Linde, Uppsala: Sveriges lantbruksuniv., Acta Universitatis agriculturae Sueciae, 1652-6880 (2005).

8. C. Tarnocai, J. Canadell, E. Schuur, P. Kuhry, G. Mazhitova, and S. Zimov, Global Biogeochemy, 23, 11 (2009).

9. S. Hofle, J. Rethemeyer, C. Mueller, and S. John, Biogeosciences, 10, 3145-3158 (2013).

10. M. Schnitzer, Soil Science Society of America, 17, 77-101 (1986).

11. V.V. Terleev, A.G. Topazh, W. Mirschel, Russian Meteorology and Hydrology, 40(4), 278-285 (2015). 
12. V. Terleev, A. Nikonorov, V. Badenko, I. Guseva, Yu. Volkova, O. Skvortsova, S. Pavlov, W. Mirschel, Advances in Civil Engineering, 2016, Article ID 8176728 (2016).

13. S. Medvedev, A. Topaj, V. Badenko, V. Terleev, IFIP Advances in Information and Communication Technology, 448, 252-261 (2015).

14. V.V. Terleev, W. Mirschel, V.L. Badenko, I.Yu. Guseva, Eurasian Soil Science, 50(4), 445-455 (2017).

15. V. Terleev, A. Nikonorov, I. Togo, Y. Volkova, V. Garmanov, D. Shishov, V. Pavlova, N. Semenova, W. Mirschel, Procedia Engineering, 165, 1776-1783 (2016).

16. N. Arefiev, V. Terleev, V. Badenko, Procedia Engineering, 117, 39-44 (2015).

17. M. Nikitina, L. Popova, J. Korobicina, O. Efremova, A. Trofimova, E. Nakvasina, A. Volkov, Journal of Elementology, 20, 643-651 (2015).

18. A. Makarov, A. Mihailova, N. Arefiev, S. Pavlov, T. Chashchina, V. Terleev, V. Badenko, Procedia Engineering, 117, 225-231 (2015).

19. N. Arefiev, V. Badenko, A. Nikonorov, V. Terleev, Yu. Volkova, Procedia Engineering, 117, 20-25 (2015).

20. A. Nikonorov, V. Badenko, V. Terleev, I. Togo, Y. Volkova, O. Skvortsova, O. Nikonova, Pavlov S., W. Mirschel, Procedia Engineering, 165, 1731-1740 (2016).

21. A. Nikonorov, S. Pavlov, V. Terleev, N. Arefiev, V. Badenko, Yu. Volkova, Procedia Engineering, 117, 258-263 (2015).

22. A. Nikonorov, V. Terleev, S. Pavlov, I. Togo, Y. Volkova, T. Makarova, V. Garmanov, D. Shishov, W. Mirschel, Procedia Engineering, 165, 1741-1747 (2016).

23. R.A. Poluektov, V.V. Terleev, Russian Meteorology and Hydrology, 12, 73-77 (2005).

24. V.V. Terleev, W. Mirschel, U. Schindler, K.-O. Wenkel, Journal International Agrophysics, 24(4), 381-387 (2010).

25. V. Badenko, V. Terleev, A. Topaj, Applied Mechanics and Materials, 635-637, 16881691 (2014).

26. V.V. Terleev, A.O. Nikonorov, I. Togo, Yu.V. Volkova, R.S. Ginevsky, V.A. Lazarev, E.R. Khamzin, V.V. Garmanov, W. Mirschel, L.I. Akimov, Magazine of Civil Engineering, 2, 84-92 (2017). 